University of Nebraska - Lincoln

DigitalCommons@University of Nebraska - Lincoln

Papers in Plant Pathology

Plant Pathology Department

2012

Spatial Patterns of Brown Rot Epidemics and

Development of Microsatellite Markers for Analyzing Fine-Scale Genetic Structure of Monilinia fructicola Populations Within Peach Tree Canopies

Sydney E. Everhart

University of Nebraska-Lincoln, everhart@unl.edu

A. Askew

University of Georgia, Athens

L. Seymour

University of Georgia, Athens

T. C. Glenn

University of Georgia, Athens

H. Scherm

University of Georgia, Athens, scherm@uga.edu

Follow this and additional works at: http://digitalcommons.unl.edu/plantpathpapers

Part of the Other Plant Sciences Commons, Plant Biology Commons, and the Plant Pathology Commons

Everhart, Sydney E.; Askew, A.; Seymour, L.; Glenn, T. C.; and Scherm, H., "Spatial Patterns of Brown Rot Epidemics and Development of Microsatellite Markers for Analyzing Fine-Scale Genetic Structure of Monilinia fructicola Populations Within Peach Tree Canopies" (2012). Papers in Plant Pathology. 367.

http://digitalcommons.unl.edu/plantpathpapers/367

This Article is brought to you for free and open access by the Plant Pathology Department at DigitalCommons@University of Nebraska - Lincoln. It has been accepted for inclusion in Papers in Plant Pathology by an authorized administrator of DigitalCommons@University of Nebraska - Lincoln. 
Citation: Everhart, S. E., Askew, A., Seymour, L., Glenn, T. C., and Scherm, H. 2012. Spatial patterns of brown rot epidemics and development of microsatellite markers for analyzing finescale genetic structure of Monilinia fructicola populations within peach tree canopies. Online. Plant Health Progress doi:10.1094/PHP-2012-0723-04-RS.

http://www.plantmanagementnetwork.org/pub/php/symposium/melhus/2011/peach/

Copyright (C) 2012 Plant Management Network.

Accepted for publication 23 May 2012. Published 23 July 2012.

\title{
Spatial Patterns of Brown Rot Epidemics and Development of Microsatellite Markers for Analyzing Fine-Scale Genetic Structure of Monilinia fructicola Populations Within Peach Tree Canopies
}

\section{S. E. Everhart, Department of Plant Pathology}
A. Askew and L. Seymour, Department of Statistics
T. C. Glenn, Department of Environmental Health Science,
H. Scherm, Department of Plant Pathology, University of Georgia, Athens, GA 30602

Corresponding author: H. Scherm. scherm@uga.edu

\begin{abstract}
To better understand the fine-scale spatial dynamics of brown rot disease and corresponding fungal genotypes, we analyzed three-dimensional spatial patterns of pre-harvest fruit rot caused by Monilinia fructicola in individual peach tree canopies and developed microsatellite markers for canopy-level population genetics analyses. Using a magnetic digitizer, high-resolution maps of fruit rot development in five representative trees were generated, and M. fructicola was
\end{abstract}


isolated from each affected fruit. To characterize disease aggregation, nearest-neighbor distances among symptomatic fruit were calculated and compared with appropriate random simulations. Within-canopy disease aggregation correlated negatively with the number of diseased fruit per tree $(r=-0.827, P=0.0009)$, i.e., aggregation was greatest when the number of diseased fruit was lowest. Sixteen microsatellite primers consistently amplified polymorphic regions in a geographically diverse test population of $47 \mathrm{M}$. fructicola isolates. None of the test isolates produced identical multilocus genotypes, and the number of alleles per locus ranged from 2 to 16. We are applying these markers to determine fine-scale population structure of the pathogen within and among canopies.

\section{Introduction}

Analysis of spatial patterns of plant disease in orchard crops can help shed light on the relative importance of different inoculum sources and potential mechanisms of dissemination within and among trees $(6,30,33)$. Most studies have focused on quantifying two-dimensional patterns of disease among trees (i.e., on an $x-y$ plane), whereas the number of studies explicitly considering three-dimensional disease patterns within canopies (i.e., in an $x-y-z$ cube) has been limited $(2,16,28)$. This is largely due to difficulties associated with accurately mapping and analyzing the hundreds or thousands of points that make up the structurally complex tree canopy. In a previous proof-of-concept study (7), we utilized a magnetic digitizer to map different brown rot symptom types (blossom blight, shoot blight, and twig cankers) caused by Monilinia laxa in individual sour cherry (Prunus cerasus) canopies, and applied nearest-neighbor-based, three-dimensional methods of spatial statistics to the resultant data points. This enabled us to determine the level of aggregation of different symptom types in the canopy as well as the degree of association of current year's symptoms with symptoms from previous year's infections. However, since the assessment and mapping in the pilot study were done at a single point in time, prior to the period of fruit maturation, it was not possible to analyze spatio-temporal disease development or to quantify spatial patterns of pre-harvest fruit rot, the most important symptom type, within the canopy. Based on these considerations, we designed a multi-year follow-up study on peach (Prunus persica) to monitor the within-canopy development of brown rot (caused by Monilinia fructicola) during the course of the season, with special emphasis on the pre-harvest fruit rot phase. Results from five trees monitored in detail during the 2009 growing season are presented herein.

The spatial analysis approach described above considers only phenotypic information, i.e., the location of each symptomatic element (e.g., brown rot-affected fruit) within the canopy. Deeper insight into disease progression may be obtained by including genotypic data about the fungal isolates associated with each symptom. Such information could then be subjected to spatial analysis to describe fine-scale genetic structure within and across canopies (29). This requires isolation of the pathogen from each georeferenced symptomatic element, as well as the availability of suitable markers for quantifying fine-scale genetic structure of $M$. fructicola populations. Most previous studies of the population structure of Monilinia spp. in stone fruit orchards $(6,10,11,20,26,27)$ have utilized marker systems with low resolution (e.g., vegetative compatibility groups) or low reproducibility (e.g., RAPDs), hence there is a need to develop a 
new set of genetic markers for $M$. fructicola that are robust, have high resolution, and are codominant to potentially resolve heterokaryiotic isolates. Based on these considerations, a second objective of this study was to develop microsatellite markers for population genetics analysis in M. fructicola. Microsatellites are tandem repeated motifs (simple sequence repeats, SSRs) of 1 to 6 bases that are located in both coding and non-coding regions and occur with a high degree of length variation, likely due to slippage during DNA replication $(22,23)$. The major drawback in using microsatellites is that they need to be isolated de novo in each species of interest. However, once developed, the procedure for analyzing and scoring individuals is relatively simple (23).

The purpose of this paper is to report preliminary results of characterizing within-canopy spatial patterns of brown rot epidemics in peach during the pre-harvest fruit rot epidemic, and to describe a set of microsatellite markers developed for M. fructicola that can be used for finescale genetic analysis of pathogen populations within tree canopies.

\section{Spatial Data Collection}

The study was conducted from late March to September 2009 in a research peach orchard at the University of Georgia Horticulture Farm in Watkinsville, GA. The orchard was established in 2000 with six peach cultivars of varying maturity dates, planted in replicated four-tree plots. During the study, no fungicide applications to control brown rot were made, but foliar sprays of wettable sulfur were applied during the cover spray period to suppress peach scab (caused by Fusicladium carpophilum); measures for thinning and arthropod and weed management followed standard commercial practice (14). Six trees were pre-selected at the beginning of the season for initial disease monitoring, and 10 additional trees were added in mid-season, prior to fruit rot development. The selection was based on criteria such as having characteristic canopy size (approximately 1.6 to $2.0 \mathrm{~m}$ high and 3.4 to $5.8 \mathrm{~m}$ wide) and a spherical to oblong canopy without major gaps, representing different maturity classes, and including trees with and without blossom blight symptoms in the spring. This set of 16 trees was purposefully larger than the number of trees that could be managed later in the season for detailed disease assessment, highresolution symptom mapping, and pathogen isolation from all symptomatic elements. As the season progressed, trees were eliminated from the monitoring based on factors such as lack of disease development, limb breakage, and bird or insect damage to fruit. This process of elimination resulted in a final set of five trees of different maturity groups and with varying levels of disease incidence at the end of the 2009 harvest season (Table 1). 
Table 1. Spatial point patterns of pre-harvest brown rot, caused by Monilinia fructicola, in five intensively mapped peach tree canopies.

\begin{tabular}{|c|c|c|c|c|c|c|c|}
\hline Tree $^{x}$ & $\begin{array}{l}\text { Total } \\
\text { fruit }\end{array}$ & $\begin{array}{l}\text { Assess- } \\
\text { ment } \\
\text { period }^{y}\end{array}$ & $\begin{array}{l}\text { Sympto- } \\
\text { matic } \\
\text { fruit }\end{array}$ & $\begin{array}{l}\text { Disease } \\
\text { incid. } \\
(\%)\end{array}$ & $d_{w^{z}}$ & $\begin{array}{c}\boldsymbol{P} \\
\text { value }\end{array}$ & Pattern \\
\hline Redglobe 7 & 248 & $\begin{array}{l}\text { Early } \\
\text { Mid } \\
\text { Late }\end{array}$ & $\begin{array}{l}26 \\
63 \\
87\end{array}$ & $\begin{array}{l}10.5 \\
25.4 \\
35.1\end{array}$ & $\begin{array}{l}0.135 \\
0.116 \\
0.099\end{array}$ & \begin{tabular}{|l|}
0.812 \\
0.454 \\
0.405
\end{tabular} & $\begin{array}{l}\text { Random } \\
\text { Random } \\
\text { Random }\end{array}$ \\
\hline O’Henry 26 & 244 & $\begin{array}{l}\text { Early } \\
\text { Mid } \\
\text { Late }\end{array}$ & $\begin{array}{c}35 \\
128 \\
142\end{array}$ & $\begin{array}{l}14.3 \\
52.5 \\
58.2\end{array}$ & $\begin{array}{l}\frac{0.360}{0.079} \\
0.047\end{array}$ & $\begin{array}{l}0.003 \\
0.342 \\
0.806\end{array}$ & $\begin{array}{l}\text { Aggregated } \\
\text { Random } \\
\text { Random }\end{array}$ \\
\hline O’Henry 127 & 126 & $\begin{array}{l}\text { Early } \\
\text { Late }\end{array}$ & $\begin{array}{l}25 \\
38\end{array}$ & $\begin{array}{l}19.8 \\
30.2\end{array}$ & $\underline{0.359}$ & $\begin{array}{l}0.024 \\
0.026\end{array}$ & $\begin{array}{l}\text { Aggregated } \\
\text { Aggregated }\end{array}$ \\
\hline $\begin{array}{l}\text { Flame- } \\
\text { prince } 45\end{array}$ & 385 & $\begin{array}{l}\text { Early } \\
\text { Late }\end{array}$ & $\begin{array}{l}122 \\
169\end{array}$ & $\begin{array}{l}31.7 \\
43.9\end{array}$ & $\begin{array}{l}-0.116 \\
-0.064\end{array}$ & $\begin{array}{l}0.097 \\
0.450\end{array}$ & $\begin{array}{l}\text { Random } \\
\text { Random }\end{array}$ \\
\hline $\begin{array}{l}\text { Flame- } \\
\text { prince } 120\end{array}$ & 396 & $\begin{array}{l}\text { Early } \\
\text { Late }\end{array}$ & $\begin{array}{r}76 \\
128\end{array}$ & $\begin{array}{l}19.2 \\
32.3\end{array}$ & $\begin{array}{l}0.128 \\
0.054\end{array}$ & $\begin{array}{l}0.256 \\
0.821\end{array}$ & $\begin{array}{l}\text { Random } \\
\text { Random }\end{array}$ \\
\hline
\end{tabular}

${ }^{\mathrm{x}}$ Arranged in order from earliest to latest-maturing cultivar.

${ }^{\mathrm{y}}$ Trees were monitored for disease at 1- to 4-day intervals during the pre-harvest period, and data are summarized for two or three assessment periods for each tree to facilitate data presentation and analysis.

${ }^{\mathrm{z}} d_{w}$ represents the index of disease aggregation and is calculated based on the cumulative frequency distribution of nearest-neighbor distances among brown rot-affected fruit. Significant positive values $(P \leq 0.05$, underlined) indicate aggregation, whereas significant negative values correspond to a more regular distribution compared with the random simulation.

At 3- to 10-day intervals from bloom through final fruit swell and then continuing at 1- to 4-day intervals until the tree-ripe stage of fruit development, trees were monitored visually for symptoms associated with $M$. fructicola infections, including blossom blight, twig blight, twig cankers, green fruit rot, and brown rot of mature fruit. When a new symptom was found, it was swabbed with a sterile cotton-tipped applicator to sample conidia, and a plastic tag was tied to the branch, proximal to the point where the symptomatic element originated. Each symptomatic element was given a unique identifier associated with the tag and the fungal isolate obtained. Thus, the location and approximate date of appearance of each symptom and corresponding isolate was known.

When fruit had reached commercial maturity, high-resolution three-dimensional maps were made for each of the five trees using a FASTRAK 3Space magnetic digitizer (Polhemus, 
Colchester, VT) (24). This device creates an electromagnetic field within which a stylus is used to obtain coordinates of objects relative to an emitter. The $x, y$, and $z$-coordinates of all tags (corresponding to symptomatic elements) were digitized using the stylus, as were all symptomatic and asymptomatic fruit for a total of up to 396 data points per tree. Having a record of the approximate date of appearance of each symptomatic element allowed the production of temporal maps of the symptoms present up to each assessment date (Fig. 1).
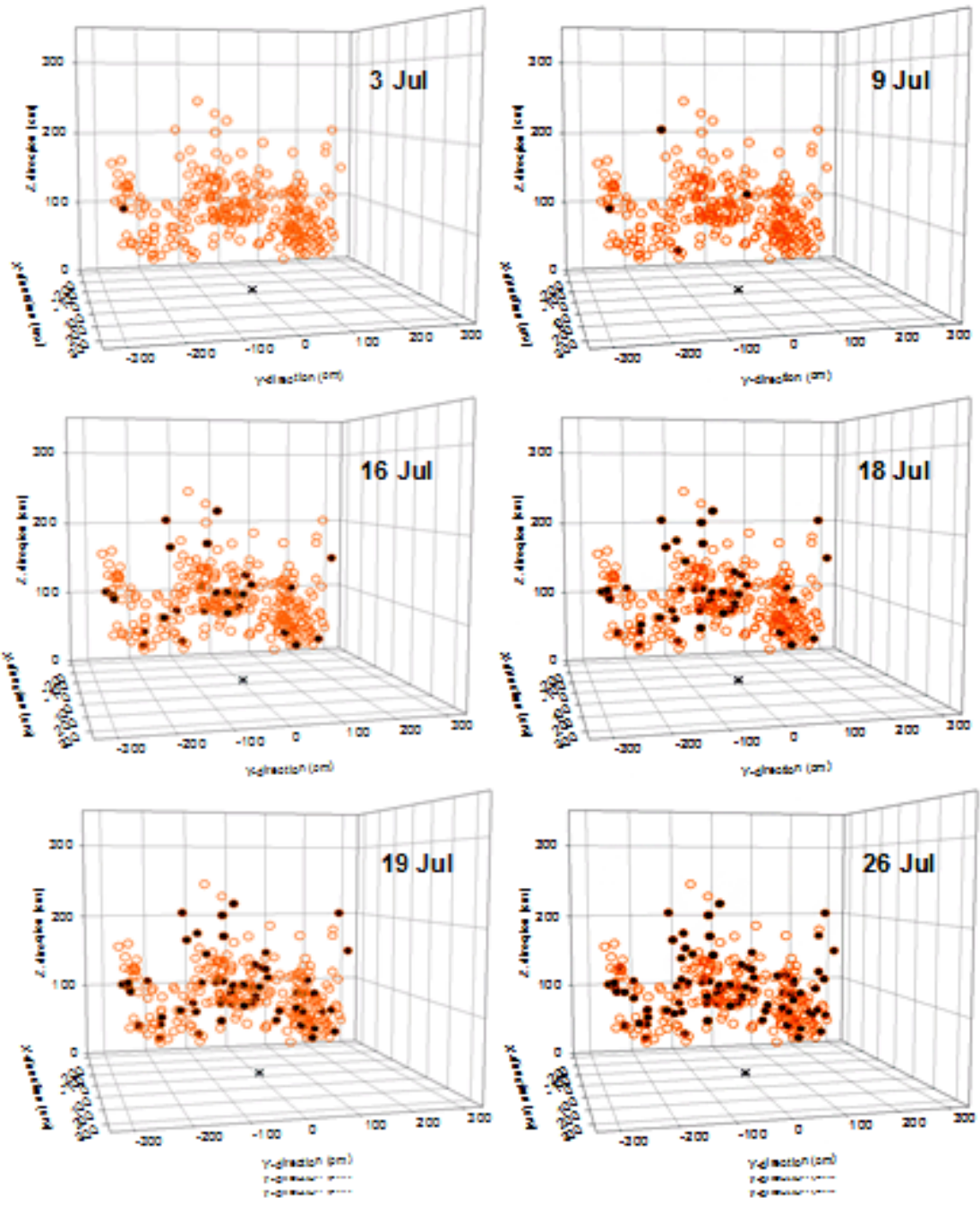

Fig. 1. Three-dimensional canopy map of peach tree Redglobe 7 showing the spatial location of each peach fruit and the development of brown rot on selected assessment dates from 3 through 26 July 2009. Open and closed symbols represent asymptomatic and symptomatic fruit, respectively. The $\mathrm{X}$ symbol marks the base of the trunk. 
Spatial Pattern Analysis

Spatial patterns of aggregation of fruit affected by brown rot within the canopy were characterized based on the frequency distribution of nearest-neighbor distances among symptoms in each tree $(4,21)$, as in Everhart et al. (7). To obtain an appropriate random distribution of the same number of symptoms for comparison, the measured coordinates of all fruit (symptomatic + asymptomatic) served as an empty set of coordinates over which the symptomatic fruit were assigned randomly to generate 1000 Monte-Carlo simulations for each tree. The cumulative frequency distribution of the observed nearest-neighbor distances among affected fruit was compared with that of the simulations using a Kolmogorov-Smirnov test. If symptoms were more aggregated than when assigned randomly, the cumulative frequency distribution would be above the upper $95 \%$ confidence band for the simulations, whereas if data were regular it would fall below the lower confidence band. The test statistic $d_{w}$, the maximum vertical departure of the observed cumulative frequency distribution from that obtained for the simulations, was used as an index of aggregation (4). A significant positive value of $d_{w}$ indicates aggregation, whereas a significant negative value signifies uniformity. Cumulative frequency distributions of nearestneighbor distances and the resultant $d_{w}$ values were used to assess the magnitude and significance of deviation from randomness. All calculations were carried out in Matlab R2011b (Mathworks, Natick, MA).

\section{Development of Microsatellite Markers}

Microsatellite markers were developed following the general protocol of Glenn and Schable (12). DNA from isolate MfLittle of M. fructicola (isolated from the UGA Horticulture Farm in 2008) was digested with Rsa I (New England Biolabs, Ipswich, MA), after which SuperSNX24 linkers (Forward 5'-GTTTAAGGCCTAGCTAGCAGCAGAATC and Reverse 5'GATTCTGCTAGCTAGGCCTTAAACAAAA) were ligated at the ends, enabling enrichment via PCR. The resulting product was probed for microsatellite repeats (di-, tri-, and tetranucleotide repeats) using complementary biotinylated oligonucleotides ligated to strepavadin-coated magnetic beads (Dynabeads; Invitrogen, Carlsbad, CA), which enabled hybridization-capture of fragments with microsatellite repeats. The enriched/recovered DNA was subsequently incorporated into a cloning vector (TOPO TA kit; Invitrogen), which resulted in a library of 159 transformed E. coli colonies that was sequenced and yielded 58 unique microsatellite repeats.

Amplification primers were designed for 54 microsatellite repeats with suitable flanking sequence (8). To enable indirect fluorescent labeling, primer pairs were synthesized with the addition of a CAG label (CAGTCGGGCGTCATCA added to the 5'-end of the shorter primer), and each PCR reaction included a HEX-labeled primer complementary to the CAG-label $(3,9)$. In total, 40 microsatellite primers and 12 polymorphic microsatellite markers previously developed for Sclerotinia spp. $(25,32)$, members of the same family as Monilinia spp., were synthesized and screened for amplification with a preliminary subset of seven isolates of $M$. fructicola (7O, 26-N14, D92-2C, W619H, AP16.04, BGA7.04, and SCDL21). All DNA extractions utilized aerial mycelium from 7-day-old cultures and were performed using the 
DNeasy Plant Mini Kit (Qiagen, Valencia, CA). PCR reactions were mixed using hot-start Taq (JumpStart Taq; Sigma-Aldrich, St. Louis, MO) following the manufacturer's reaction specifications, scaled to $25 \mu \mathrm{L}$, and modified to contain a 1:10 ratio of CAG-labeled-primer to CAG label. PCR conditions utilized a touchdown treatment where 20 cycles from 60 to $50.5^{\circ} \mathrm{C}$ enabled a range of primer melting temperatures to be met, followed by 15 cycles to increase the number of amplicons (5). Specifically, thermocycle conditions consisted of an initial treatment at $95^{\circ} \mathrm{C}$ for $2.5 \mathrm{~min} ; 20 \mathrm{cycles}$ of $95^{\circ} \mathrm{C}$ for $20 \mathrm{sec}, 60^{\circ} \mathrm{C}$ for $20 \mathrm{sec}$ (decreased by $0.5^{\circ} \mathrm{C}$ for every cycle), and $72^{\circ} \mathrm{C}$ for $30 \mathrm{sec}$; followed by 15 cycles of $95^{\circ} \mathrm{C}$ for $20 \mathrm{sec}, 50^{\circ} \mathrm{C}$ for $20 \mathrm{sec}$, and $72^{\circ} \mathrm{C}$ for $30 \mathrm{sec}$. A 1:10 dilution of amplicons was denatured and analyzed using capillary electrophoresis (3730xl DNA Analyzer; Applied Biosystems, Carlsbad, CA). From the 52 primer sets screened, six yielded amplification in all seven isolates, 11 required re-design of one or both primers to amplify the locus in all isolates, and 35 did not amplify sufficiently (including all those developed previously for Sclerotinia spp.). Ultimately, 17 functional primer sets were developed for preliminary polymorphism screening.

To assess markers for polymorphisms, DNA was purified from a test set of 47 isolates of $M$. fructicola obtained from stone fruit production regions in middle Georgia, north Georgia, North Carolina, South Carolina, and Virginia (Table 2). These isolates had been collected either from diseased fruit or blossoms of peach or plum (Prunus domestica) between 1982 and 2010. All 17 loci showed amplification, but one locus had more than $10 \%$ null alleles and was therefore excluded. Locus Mf-SEA and Mf-SEK yielded two and one null allele(s), but this was not considered sufficient for exclusion. Subsequent data analysis to examine the number of alleles per locus and haploid genetic diversity were performed using GenAlEx $6.4(18,19)$. Using Multilocus $1.3 \mathrm{~b}(1)$, we calculated the multilocus genotype saturation curve as well as the index of association, $I_{\mathrm{A}}$ (to test whether two individuals that are the same at one locus are more likely to be the same at another). Finally, the 16 microsatellite primers were screened against four isolates of M. laxa (ML15FC and ML11 from Italy, Holb2 from Hungary, and Quince2010 from Delaware) to determine their utility for population genetics analyses in this closely related species. However, none of the primer pairs sufficiently cross-amplified to warrant further development for M. laxa (data not shown).

Table 2. Primer details, core sequences, allelic properties, and gene diversity $(h)$ of 16 polymorphic PCR-based microsatellite markers developed for Monilinia fructicola and evaluated in a test population of 47 isolates. 
Table 2 from:

Everhart, S. E., Askew, A., Seymour, L., Glenn, T. C., and Scherm, H. 2012. Spatial patterns of brown rot epidemics and development of microsatellite markers for analyzing fine-scale genetic structure of Monilinia fructicola populations within peach tree canopies. Online. Plant Health Progress doi:10.1094/PHP-2012-0723-04-RS.

Table 2. Primer details, core sequences, allelic properties, and gene diversity $(h)$ of 16 polymorphic PCR-based microsatellite markers developed for Monilinia fructicola and evaluated in a test population of 47 isolates.

\begin{tabular}{|c|c|c|c|c|c|c|c|c|c|}
\hline \multirow[b]{2}{*}{ Locus } & \multirow[b]{2}{*}{ Primer sequence (5'-3') } & \multirow[b]{2}{*}{$\begin{array}{l}\text { Repeat } \\
\text { motif }\end{array}$} & \multirow{2}{*}{$\begin{array}{c}\text { Cloned } \\
\text { allele } \\
\text { (bp) }\end{array}$} & \multirow{2}{*}{$\begin{array}{c}\text { Size } \\
\text { range } \\
\text { (bp) }\end{array}$} & \multirow[b]{2}{*}{$\begin{array}{l}\text { No. of } \\
\text { alleles }\end{array}$} & \multicolumn{3}{|c|}{$\begin{array}{l}\text { No. of alleles for sub- } \\
\text { populations }^{\mathrm{x}}\end{array}$} & \multirow[b]{2}{*}{$\boldsymbol{h}$} \\
\hline & & & & & & $\begin{array}{l}\text { Middle } \\
\text { GA }\end{array}$ & $\begin{array}{l}\text { North } \\
\text { GA }\end{array}$ & Carolinas & \\
\hline \multirow{2}{*}{$\begin{array}{l}\text { Mf- } \\
\text { SEA }\end{array}$} & GAGTTTTCGGGATGGGGAG & \multirow[b]{2}{*}{$(\mathrm{CTTT})^{9}$} & \multirow[b]{2}{*}{139} & \multirow{2}{*}{$\begin{array}{l}124- \\
156\end{array}$} & \multirow[b]{2}{*}{8} & \multirow[b]{2}{*}{6} & \multirow[b]{2}{*}{5} & \multirow[b]{2}{*}{4} & \multirow[b]{2}{*}{0.519} \\
\hline & $\begin{array}{l}\text { (CAG)- } \\
\text { AACTGATATACGAACTTCTAGGAC }\end{array}$ & & & & & & & & \\
\hline \multirow{2}{*}{$\begin{array}{l}\text { Mf- } \\
\text { SEB }\end{array}$} & $\begin{array}{l}\text { (CAG)- } \\
\text { AGGATTCGTCAAGAAGTCAATC }\end{array}$ & \multirow[t]{2}{*}{$(\mathrm{GGAT})^{10}$} & \multirow[t]{2}{*}{129} & \multirow{2}{*}{$\begin{array}{l}119- \\
231\end{array}$} & \multirow[t]{2}{*}{16} & \multirow[t]{2}{*}{7} & \multirow[t]{2}{*}{9} & \multirow[t]{2}{*}{8} & \multirow[t]{2}{*}{0.905} \\
\hline & TCTGCGTATTTATTACTTTGGGTAG & & & & & & & & \\
\hline \multirow{2}{*}{$\begin{array}{l}\text { Mf- } \\
\text { SEC }\end{array}$} & СТCTCAACACCTGGGCATTC & \multirow{2}{*}{$\begin{array}{l}(\mathrm{AATC})^{5} \\
(\mathrm{CATT})^{5}\end{array}$} & \multirow[b]{2}{*}{139} & \multirow{2}{*}{$\begin{array}{c}144- \\
199\end{array}$} & \multirow[b]{2}{*}{15} & \multirow[b]{2}{*}{8} & \multirow[b]{2}{*}{9} & \multirow[b]{2}{*}{9} & \multirow[b]{2}{*}{0.907} \\
\hline & $\begin{array}{l}\text { (CAG)- } \\
\text { GAAGAGAGGGAAAGAGAGCG }\end{array}$ & & & & & & & & \\
\hline \multirow{3}{*}{$\begin{array}{l}\text { Mf- } \\
\text { SED }\end{array}$} & (CAG)-TTGGCATGGCATTTGGAGC & \multirow{2}{*}{$(\mathrm{GGAT})^{6}$} & \multirow{2}{*}{106} & \multirow{2}{*}{$\begin{array}{c}111- \\
149\end{array}$} & 12 & 0 & 7 & 7 & 0075 \\
\hline & CCATTTTATTCATATCCAACGCCC & & & & 12 & 9 & 7 & 7 & 0.875 \\
\hline & (CAG)-TGGACCAACACAGCTACGG & $(\mathrm{GT})^{12}$ & 128 & & 2 & 1 & 2 & 2 & 0.083 \\
\hline
\end{tabular}




\begin{tabular}{|c|c|c|c|c|c|c|c|c|c|}
\hline $\begin{array}{l}\text { Mf- } \\
\text { SEE }\end{array}$ & GGGTCCTCGCGTTTGATTTG & & & $\begin{array}{l}144- \\
152\end{array}$ & & & & & \\
\hline \multirow{2}{*}{$\begin{array}{l}\text { Mf- } \\
\text { SEF }\end{array}$} & TGTCTCTCAACTTTTAAATCAGCC & \multirow[b]{2}{*}{$(\mathrm{AATC})^{8}$} & \multirow[b]{2}{*}{113} & \multirow{2}{*}{$\begin{array}{l}111- \\
156\end{array}$} & \multirow[b]{2}{*}{11} & \multirow[b]{2}{*}{6} & \multirow[b]{2}{*}{8} & \multirow[b]{2}{*}{5} & \multirow[b]{2}{*}{0.850} \\
\hline & $\begin{array}{l}\text { (CAG)- } \\
\text { GACTATAGAGTTTTCTACGGATGG }\end{array}$ & & & & & & & & \\
\hline \multirow{2}{*}{$\begin{array}{l}\text { Mf- } \\
\text { SEG }\end{array}$} & $\begin{array}{l}\text { (CAG)- } \\
\text { CCTACCCAATCTACCTAGTAACC }\end{array}$ & \multirow[t]{2}{*}{$(\mathrm{AGGATG})^{4}$} & \multirow[t]{2}{*}{124} & \multirow[t]{2}{*}{ 99-139 } & \multirow[t]{2}{*}{4} & \multirow[t]{2}{*}{2} & \multirow[t]{2}{*}{4} & \multirow[t]{2}{*}{2} & \multirow[t]{2}{*}{0.549} \\
\hline & CCAAAGCAAAGTAGAGCAAAGC & & & & & & & & \\
\hline \multirow{2}{*}{$\begin{array}{l}\text { Mf- } \\
\text { SEI }\end{array}$} & (CAG)-CTCAAGCGGTGGCTCAAAG & \multirow{2}{*}{$(\mathrm{ATC})^{7}$} & \multirow{2}{*}{87} & \multirow{2}{*}{$91-139$} & \multirow{2}{*}{10} & \multirow{2}{*}{6} & \multirow{2}{*}{7} & \multirow{2}{*}{4} & \multirow{2}{*}{0.746} \\
\hline & TAACCACCACGACCACGAC & & & & & & & & \\
\hline \multirow{2}{*}{$\begin{array}{l}\text { Mf- } \\
\text { SEJ }\end{array}$} & $\begin{array}{l}\text { (CAG)- } \\
\text { TCCTTTCCGTTCCTCTTCCTG }\end{array}$ & \multirow[t]{2}{*}{$(\mathrm{CCTTT})^{4}$} & \multirow[t]{2}{*}{89} & \multirow[t]{2}{*}{$97-132$} & \multirow[t]{2}{*}{6} & \multirow[t]{2}{*}{6} & \multirow[t]{2}{*}{8} & 3 & 0.735 \\
\hline & CCGACGACAGACCAACAAAC & & & & & & & & \\
\hline Mf- & (CAG)-GCTACTAAGAGCCTAGCG & $(\mathrm{C} \wedge \mathrm{TT})^{6}$ & 2027 & $228-$ & 12 & 7 & 6 & 0 & 0872 \\
\hline SEK & TGCTTTACTGGAGCTGTGTTTG & $(C A 11)$ & 221 & 268 & 15 & 1 & 0 & 9 & 0.012 \\
\hline Mf- & $\begin{array}{l}\text { (CAG)- } \\
\text { GAGTATAACCAACCCAACGGC }\end{array}$ & $(\mathrm{CATT})^{7}$ & 127 & $135-$ & 4 & 3 & 4 & 3 & 0.726 \\
\hline SEL & AGAGATGGAGTCAGGAGTGTTG & & & & & & & & \\
\hline Mf- & (CAG)-GGGAGAGTGGGAGATTGGG & $(\mathrm{ACTC})^{7}$ & 108 & $121-$ & 12 & 9 & 7 & 6 & 0892 \\
\hline SEM & GGGACCCTTGGACAGCAG & $(A C T C)^{\prime}$ & 108 & 187 & 12 & 9 & & & 0.892 \\
\hline Mf- & (CAG)-TGCGTGTCATGTCGTCC & $(C T)^{12}$ & 138 & $219-$ & 5 & 3 & 5 & 4 & 0742 \\
\hline SEN & CGAGGCTTAACTTCCGTGC & (C1) & 150 & 252 & $J$ & $J$ & & 4 & \\
\hline Mf- & (CAG)-TCCCATACTAGGCCACAGC & $(\mathrm{ACCT})^{6}$ & 233 & $242-$ & 8 & 5 & 6 & 2 & 0.629 \\
\hline SEP & ATCAATTGGTTTGGGTCCTTG & $(A C C 1)^{\circ}$ & 233 & 270 & 8 & 5 & 6 & 2 & 0.629 \\
\hline & (CAG)-GGAGGTGGATGGTGGGTAG & $(\mathrm{AG})^{10}$ & 131 & & 8 & 4 & 6 & 6 & 0.837 \\
\hline
\end{tabular}




\begin{tabular}{|c|c|c|c|c|c|c|c|c|c|}
\hline $\begin{array}{l}\text { Mf- } \\
\text { SEQ }\end{array}$ & TGGCTGTGGGTTGAGTGAG & & & $\begin{array}{l}129- \\
143\end{array}$ & & & & & \\
\hline \multirow{2}{*}{$\begin{array}{l}\text { Mf- } \\
\text { SER }\end{array}$} & (CAG)-GCGTGCGGCCTATCAAAC & \multirow{2}{*}{$(\mathrm{ACCT})^{6}$} & \multirow{2}{*}{117} & \multirow{2}{*}{$\begin{array}{c}130- \\
182\end{array}$} & \multirow{2}{*}{10} & \multirow{2}{*}{6} & \multirow{2}{*}{7} & \multirow{2}{*}{4} & \multirow{2}{*}{0.722} \\
\hline & TGCTTGGATTTTCTGTGAAGGG & & & & & & & & \\
\hline
\end{tabular}

${ }^{\mathrm{x}}$ Test populations were obtained from stone fruit production regions in middle Georgia $(n=14$ isolates); north Georgia $(n=21)$; and North Carolina, South Carolina, and Virginia $(n=12)$.

(C) 2012 Plant Management Network. 
The first brown rot symptoms on ripening fruit were observed 10 to 37 days before commercial maturity, with final fruit rot incidence (at the tree-ripe stage of fruit development) reaching between 30.2 and $58.2 \%$ (Table 1). Spatial coordinates of symptomatic and asymptomatic fruit were readily collected with the magnetic digitizer (Fig. 1), whereby a single mapping of an individual tree (having 126 to 396 fruit total) required between 2 and 4 hours by a two-person team. Median nearest-neighbor distances, calculated from the spatial coordinates of each fruit, ranged from 5.7 to $14.7 \mathrm{~cm}$ among all fruit and 11.8 to $20.6 \mathrm{~cm}$ among symptomatic fruit at the time of digitization (Fig. 2).

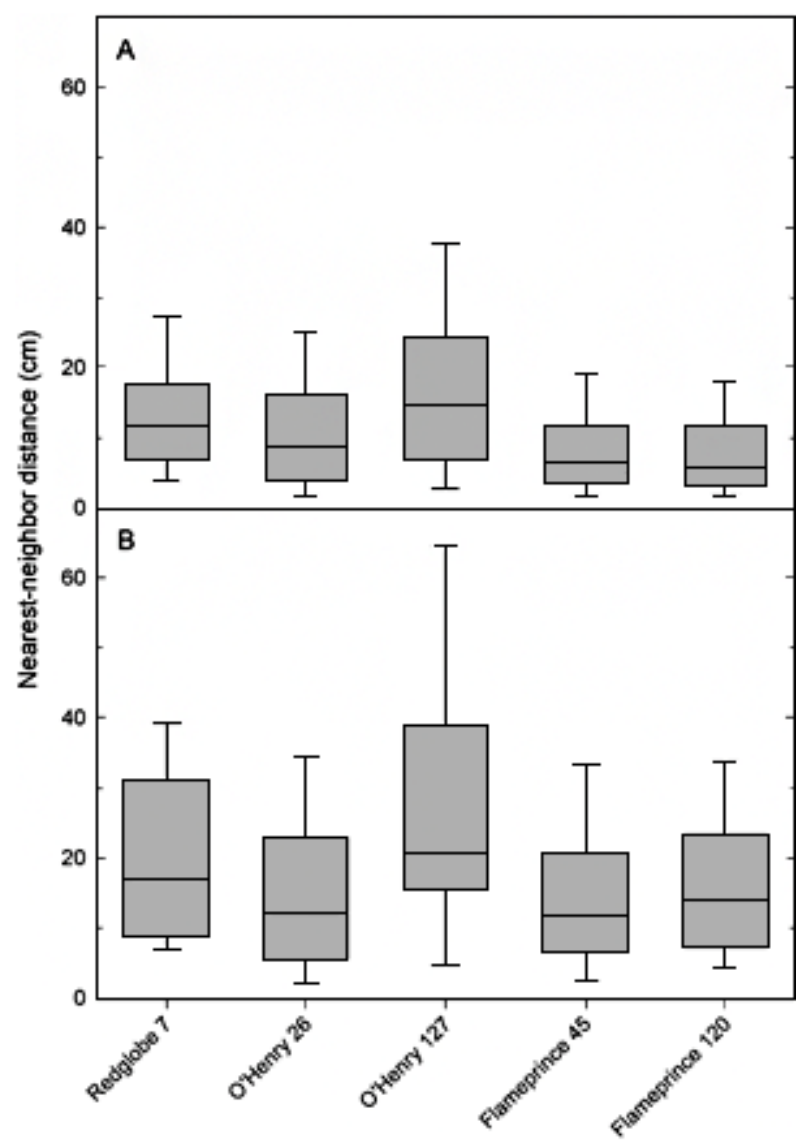

Fig. 2. Distributions of nearest-neighbor distances among all fruit (A) and among brown rot-affected fruit at the end of the epidemic (B) in five intensively mapped peach tree canopies.

For determining aggregation patterns of symptomatic fruit, epidemics were divided into two or three phases for each tree, corresponding to early, middle, and late assessment periods during the pre-harvest brown rot epidemic; the middle phase was not included for all trees (Table 1), especially where the overall duration of the epidemic was short. It is important to note that 
'early' in this context does not necessarily correspond to low disease incidence, particularly for the later-maturing trees where disease onset occurred very rapidly and reached high incidence levels within a short period (e.g., Flameprince trees 45 and 120 in Table 1). Results showed that the index of aggregation, $d_{w}$, was negatively correlated with the number of diseased fruit across all trees and phases (Fig. 3), i.e., aggregation was greatest when the number of diseased fruit was lowest. However, only the largest of the $d_{w}$ values $(>0.25)$ were significantly different from zero. Overall, three of the five trees had random patters of pre-harvest brown rot during all assessment phases, one tree had a significantly aggregated pattern of disease during all phases, and one tree had a pattern of diseased fruit that changed from significantly aggregated during the early phase to random during the mid and late season of the epidemic (Table 1).

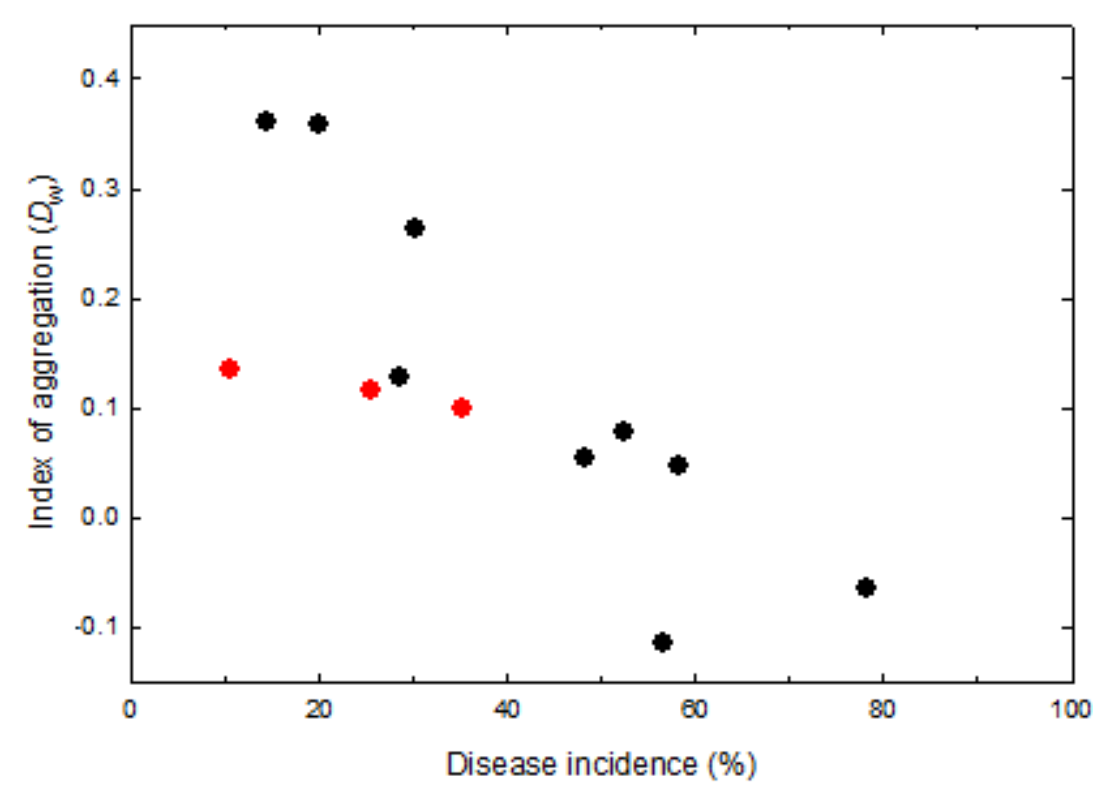

Fig. 3. Plot of $d_{w}$, an index of disease aggregation, vs. the number of brown-rot-affected fruit in five intensively mapped peach tree canopies. $d_{w}$ is calculated based on the cumulative frequency distribution of nearest-neighbor distances among brown rot-affected fruit. Positive values indicate aggregation, whereas negative values correspond to a more regular distribution compared with the random simulation. Data are from early, mid, and late assessment periods during the epidemic as shown in Table 1. Data points in red correspond to the early-maturing cultivar Redglobe 7, which suffered some bird damage to fruit.

One tree that deviated somewhat from the pattern of increased aggregation associated with lower disease incidence was Redglobe 7 (Table 1). This early-maturing tree suffered some damage from crows (Corvus brachyrhynchos) during the ripening phase, requiring bird netting to protect the tree. Despite these efforts, we cannot exclude the possibility that bird damage influenced the spatial pattern of disease in this tree, possibly leading to lower $d_{w}$ values at low incidence levels 
(Fig. 3). Indeed, when the data from Redglobe 7 were omitted from the correlation analysis shown in Fig. 3, $r$ improved from -0.827 to -0.908 and $P$ from 0.0009 to 0.0007 . Overall, these results support the notion that aggregation of disease is more pronounced with fewer inoculum sources (earlier in the pre-harvest season and/or fewer diseased fruit). That is not to say that trees with more inoculum sources lack spatial structure, but that aggregation is likely obscured by multiple, overlapping disease distributions within the same tree.

\section{Preliminary Evaluation of Microsatellite Markers}

Sixteen of the 40 primer sets evaluated consistently amplified polymorphic microsatellite regions in the test population of $47 \mathrm{M}$. fructicola isolates, with amplicons ranging from 91 to $270 \mathrm{bp}$ in length (Table 2). Although previous cytological studies have shown that fungi in the genus Monilinia are multinucleate $(\sim 5$ to 10 nuclei per conidium) $(13,15,31)$, only one peak was detected for each locus, which is consistent with the haploid-monokaryotic state of other fungi in the Sclerotinaceae $(17,25,32)$. The number of alleles per locus ranged from 2 to 16 , with an average of 9 alleles per locus. With the exception of locus Mf_G6H6 for the isolates from middle Georgia, all primer pairs yielded more than one locus per region. The haploid genetic diversity at each locus was 0.519 to 0.905 , with an average of 0.724 .

Combining banding profiles across loci for each individual showed that none of the isolates produced an identical multilocus genotype. The index of association was not significant $\left(I_{\mathrm{A}}=0.086, P=0.108\right)$, indicating no multilocus linkage disequilibrium. As an indication of resolving power of these microsatellite markers, $95 \%$ of the multilocus genotypes were resolved with the use of 7 loci, and $99 \%$ of genotypes were resolved with 13 loci (Fig. 4). Thus, use of all 16 polymorphic microsatellite markers should be suitable for differentiating multilocus genotypes at a fine-scale. 


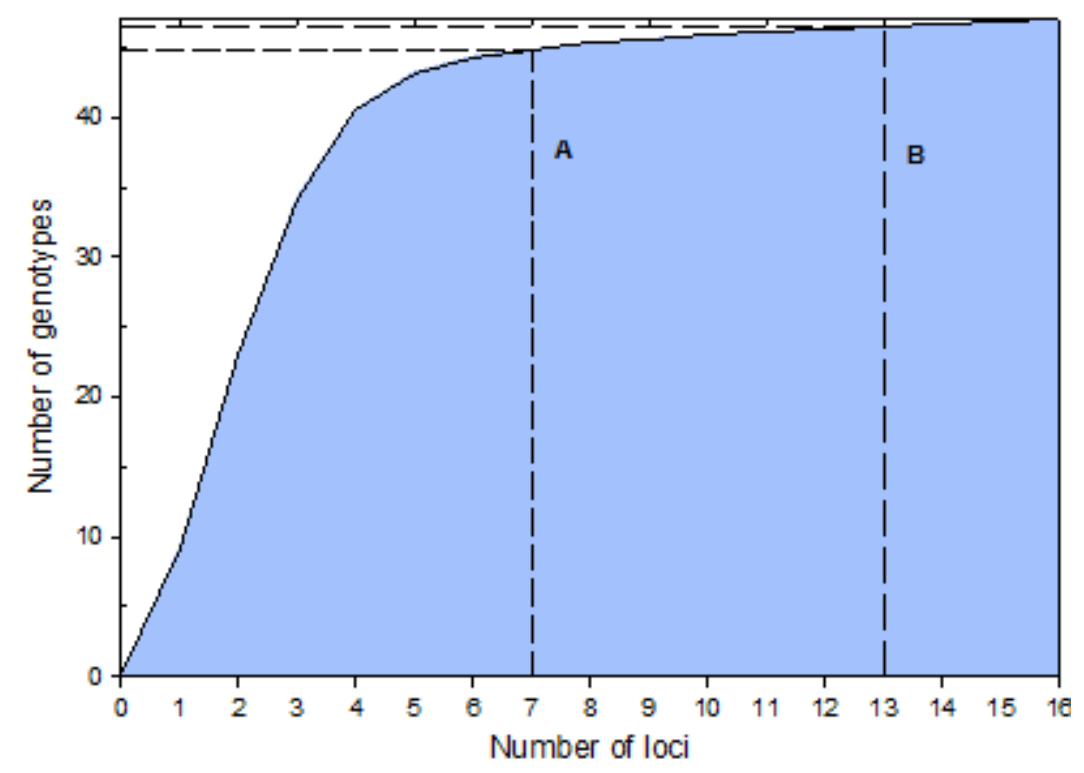

Fig. 4. Performance of 16 microsatellite markers developed de novo for Monilinia fructicola when evaluated with a test population of the fungus from stone fruit production regions in middle Georgia ( $n=14$ isolates); north Georgia $(n=21)$; and North Carolina, South Carolina, and Virginia $(n=12)$. Seven markers resolved 45 of 47 genotypes (A) whereas 13 markers resolved 46 of 47 genotypes (B).

\section{Conclusions}

The approach presented here, although preliminary with respect to the one-year data set used for illustration, provides a firm foundation for future research on canopy disease dynamics, particularly with respect to the production and analysis of high-resolution canopy disease maps. Our results showed that the relative degree of aggregation of affected fruit decreased with increasing numbers of diseased fruit. This demonstrates that two-dimensional paradigms in spatial epidemics translate to three-dimensional coordinate systems. Further interpretation of the disease patterns observed in this study will be possible through population genetics analyses of the associated pathogen isolates, for which the set of 16 microsatellites developed and characterized herein provides the necessary foundation. These markers will be used to genotype $\sim 700$ isolates collected from diseased fruit or blossoms from canopies monitored between 2009 and 2011, representing all infections within each tree during the entire season. Threedimensional spatial autocorrelation of multilocus genotypes (29) can then be applied to characterize the fine-scale spatial genetic structure of $M$. fructicola populations within trees, helping to shed light on within-tree inoculums sources and the relative contribution of sexual vs. asexual modes of pathogen reproduction during the growing season. 
Acknowledgments

Funded in part by grant no. 2009-34103-19818 from the USDA Southern Region IPM Program. We thank Guido Schnabel, David Ritchie, and Elizabeth Little for providing isolates used in microsatellite development and polymorphism screening, and Amy Savelle, Sara Thomas, and Lucky Mehra for help in digitizing tree canopies.

\section{Literature Cited}

1. Agapow, P.-M., and Burt, A. 2001. Indices of multilocus linkage disequilibrium. Mol. Ecol. Notes 1:101-102.

2. Andrews, J. H., Kenerley, C. M., and Nordheim, E. V. 1980. Positional variation in phylloplane microbial populations within an apple tree canopy. Microb. Ecol. 6:71-84.

3. Boutin-Ganache, I., Raposo, M., Raymond, M., and Deschepper, C. F. 2001. M13-tailed primers improve the readability and usability of microsatellite analyses performed with two different allele-sizing methods. BioTechniques 31:24-28

4. Coomes, D. A., Rees, M., and Turnbull, L. 1999. Identifying aggregation and association in fully mapped spatial data. Ecology 80:554-565.

5. Don, R. H., Cox, P. T., Wainwright, B. J., Baker, K., and Mattick, J. S. 1991. 'Touchdown' PCR to circumvent spurious priming during gene amplification. Nucleic Acids Res. 19:4008.

6. Elmer, P. A. G., Gaunt, R. E., and Frampton, C. M. 1998. Spatial and temporal characteristics of dicarboximide-resistant strains of Monilinia fructicola and brown rot incidence in stone fruit. Plant Path. 47:530-536.

7. Everhart, S. E., Askew, A., Seymour, L., Holb, I. J., and Scherm, H. 2011. Characterization of three-dimensional spatial aggregation and association patterns of brown rot symptoms within intensively mapped sour cherry trees. Ann. Bot. 108:1195-1202.

8. Faircloth, B. C. 2008. MSATCOMMANDER: Detection of microsatellite repeat arrays and automated, locus-specific primer design. Mol. Ecol. Resour. 8:92-94.

9. Faircloth, B. C., Terhune, T. M., Schable, N. A., Glenn, T. C., Palmer, W. E., and Carroll, J. P. 2008. Ten microsatellite loci from northern bobwhite (Colinus virginianus). Conserv. Genet. doi $10.1007 / \mathrm{s} 10592-008-9559-4$

10. Förster, H., and Adaskaveg, J. E. 1999. Early brown rot infections in sweet cherry fruit are detected by Monilinia-specific DNA primers. Phytopathology 90:171-178. 
11. Gell, I., Larena, I., and Melgarejo, P. 2007. Genetic diversity in Monilinia laxa populations in peach orchards in Spain. J. Phytopathol. 155:549-556.

12. Glenn, T. C., and Schable, N. A. 2005. Isolating microsatellite DNA loci. Methods Enzymol. 395:202-222.

13. Hall, R. 1963. Cytology of the asexual stages of the Australian brown rot fungus Monilinia fructicola (Wint.) Honey. Cytologia 28:181-193.

14. Horton, D., Brannen, P., Bellinger, B., Lockwood, D., and Ritchie, D. 2011. Southeastern peach, nectarine, and plum pest management and culture guide. Coop. Ext. Serv. Bull. 1171, Univ. of Georgia, Athens, GA.

15. Margosan, D. A., and Phillips, D. J. 1985. Effect of two temperatures on nuclear number of conidia of Monilinia fructicola. Mycologia 77:835-837.

16. Michailides, T. J., and Morgan, D. P. 1998. Spread of endosepsis in calimyrna fig orchards. Phytopathology 88:637-647.

17. Njambere, E. N., Vandemark, G., and Chen, W. 2010. Development and characterization of microsatellite markers for the fungal plant pathogen Sclerotinia trifoliorum. Genome 53:494500 .

18. Nei, M. 1973. Analysis of gene diversity in subdivided populations. Proc. Natl. Acad. Sci. 70:3321-3323.

19. Peakall, R., and Smouse, P. E. 2006. GENALEX 6: Genetic analysis in Excel. Population genetic software for teaching and research. Mol. Ecol. Notes 6:288-295.

20. Scherm, H., and Emery, K. M. 2002. Vegetative compatibility in populations of Monilinia fructicola from Georgia peach orchards. Acta Hortic. 592:725-727.

21. Scheuerell, M. D. 2004. Quantifying aggregation and association in three-dimensional landscapes. Ecology 85:2332-3240.

22. Schlötterer, C., and Tautz, D. 1992. Slippage synthesis of simple sequence DNA. Nucleic Acids Res. 20:211-215.

23. Selkoe, K. A., and Toonen, R. J. 2006. Microsatellites for ecologists: A practical guide to using and evaluating microsatellite markers. Ecol. Lett. 9:615-629.

24. Sinoquet, H., Rivet, P., and Godin, C. 1997. Assessment of the three-dimensional architecture of walnut trees using digitising. Silva Fennica 31:265-273.

25. Sirjusingh, C., and Kohn, J. M. 2001. Characterization of microsatellites in the fungal plant pathogen, Sclerotinia sclerotiorum. Mol. Ecol. Notes 1:267-269. 
26. Snyder, C. L., and Jones, A. L. 1999. Genetic variation between strains of Monilinia fructicola and Monilinia laxa isolated from cherries in Michigan. Can. J. Plant Pathol. 21:70-77.

27. Sonoda, R. M., Ogawa, J. M., and Manji, B. T. 1991. Population structure of Monilinia fructicola in Prunus persica var. nucipersica tree canopies. Mycol. Res. 95:893-895.

28. Sposito, M. B., Amorim, L., Bassanezi, R. B., Bergamin Filho, A., and Hau, B. 2008. Spatial pattern of black spot incidence within citrus trees related to disease severity and pathogen dispersal. Plant Path. 57:103-108.

29. Trapnell, D. W., Hamrick, J. L., and Nason, J. D. 2004. Three-dimensional fine-scale genetic structure of the neotropical epiphytic orchid, Laelia rubescens. Mol. Ecol. 13:1111-1118.

30. van Leeuwen, G. C. M., Stein, A., Holb, I., and Jeger, M. J. 2000. Yield loss in apple caused by Monilinia fructigena (Aderh. \& Ruhl.) Honey, and spatio-temporal dynamics of disease development. Eur. J. Plant Pathol. 106:519-528.

31. Willetts, H. J., and Calonge, F. D. 1969. Spore development in the brown rot fungi (Sclerotinia spp.). New Phytol. 68:123-131.

32. Winton, L. M., Krohn, A. L., and Leiner, R. H. 2007. Microsatellite markers for Sclerotinia subarctica nom. prov., a new vegetable pathogen of the High North. Mol. Ecol. Notes 7:10771079.

33. Xu, X.-M., Robinson, J. D., Berrie, A. M., and Harris, D. C. 2001. Spatio-temporal dynamics of brown rot (Monilinia fructigena) on apple and pear. Plant Pathol. 50:569-578. 